\title{
Gambaran Eritrosit, Leukosit dan Performa Pertumbuhan Ikan Baung (Hemibagrus nemurus) yang Diberi Pakan Dengan Penambahan Ragi Roti Komersil (Saccharomyces cerevisiae)
}

\section{Description of Erythrocyte, Leucocite and Growth Performance of Green Catfish (Hemibagrus nemurus) Feeded With Addtion of Commercial Bread (Saccharomyces cerevisiae)}

\author{
M. Idham Shilman', Windu Sukendar ${ }^{1}$, Rizal Akbar Hutagalung², Alfani Kurniawan ${ }^{1}$ \\ ${ }^{1}$ Program Studi Teknologi Budidaya Perikanan, Jurusan Ilmu Kelautan dan Perikanan, Program \\ Studi Di Luar Kampus Utama (PSDKU) POLNEP Kapuas Hulu, Jl. Danau Sentarum, \\ Kec.Putussibau Utara, Kabupaten Kapuas Hulu, Kalimantan Barat \\ ${ }^{2}$ Program Studi Budidaya Perikanan, Jurusan Ilmu Kelautan dan Perikanan, Politeknik Negeri \\ Pontianak, Jl. A. Yani, Kec. Pontianak Tenggara, Kota Pontianak, Kalimantan Barat \\ *Author : rizalakbarhutagalung.polnep@gmail.com
}

Received: 24 Agustus $2020 \quad$ Revised:7 September $2020 \quad$ Accepted: 14 September 2020

\begin{abstract}
Abstrak
Ikan Baung (Hemibagrus nemurus) merupakan salah satu spesies ikan air tawar spesies asli perairan umum Indonesia, khususnya di daerah Sumatera dan Kalimantan. Ikan baung memiliki daging yang tebal, lembut, cita rasa yang enak dan memiliki nilai ekonomis tinggi. Penelitian ini dilaksanakan di Workshop Prodi Teknologi Budidaya Perikanan, menggunakan wadah berupa bak fiber yang disekat menjadi 4 bagian $(100 \mathrm{~cm} \times 50 \mathrm{~cm} \times 7 \mathrm{~cm})$ menggunakan waring. Organisme uji berupa ikan baung dengan ukuran ikan $5 \mathrm{~cm}-$ $7 \mathrm{~cm}$ yang ditebar sebanyak 10 ekor/sekat dan dipelihara selama 60 hari. Penelitian ini menggunakan rancangan acak lengkap (RAL) dengan 4 perlakuan dan 3 ulangan. Perlakuan yang digunakan adalah penambahan ragi $S$. cerevisiae pada pakan buatan (pelet) dengan dosis berbeda. Dimana perlakuan kontrol (K): tanpa penambahan S. cerevisiae, perlakuan A (P1): dengan dosis $S$. cerevisiae $0,2 \%$, perlakuan B (P2): penambahan $S$. cerevisiae sebesar 0,5\%, dan perlakuan C(P3): dosis $S$. cerevisiae sebesar 0,8\%. Aplikasi $S$. cerevisiae menggunakan metode coating dengan frekwensi pemberian 2 kali sehari. Parameter yang diamati antara lain status kesehatan ikan (total sel darah merah, dan sel darah putih, hematokrit, hemoglobin dan glukosa darah) serta parameter produksi seperti: pertumbuhan mutlak, laju pertumbuhan harian, jumlah konsumsi pakan, rasio konversi pakan, tingkat kelangsungan hidup. Hasil penelitian menunjukan laju perumbuhan mutlak dan laju pertumbuhan harian tertinggi terdapat pada perlakuan (P2) masing masing sebesar $21.86 \pm 10,05$ gram dan $0.86 \pm 0,38 \%$. Disisi lain, nilai FCR terendah terdapat pada perlakuan (P3) yaitu sebesar 1: 1,25 $\pm 0,60$. Hal ini menunjukkan bahwa pemberian $S$. cerevisiae memberikan dampak positif terhadap peningkatan sel darah merah, sel darah putih serta performa pertumbuhan ikan baung.

Kata Kunci : Eritrosit, Leukosit, Pertumbuhan, Ikan Baung
\end{abstract}

Abstract

Baung fish (Hemibagrus nemurus) is a freshwater fish species native to Indonesian public waters, particularly in Sumatra and Kalimantan. Baung fish has thick, soft meat, delicious taste, and has high economic value. This research was conducted at the Workshop for Fisheries Cultivation Technology Study Program, using a container in the form of a fiber tub which is divided into 4 parts $(100 \mathrm{~cm} \times 50 \mathrm{~cm} \mathrm{x} 7 \mathrm{~cm})$ using waring. The test organism was fish baung with fish size $5 \mathrm{~cm}-7 \mathrm{~cm}$, which were spread as many as 10 fish/bulkhead and kept for 60 days. This study used a completely randomized design (CRD) with 4 treatments and 3 replications. The treatment used was the addition of S. cerevisiae yeast to artificial feed (pellets) with different doses. Where the control treatment $(\mathrm{K})$ : without the addition of S. cerevisiae, treatment A (P1): with 
a dose of S. cerevisiae $0.2 \%$, treatment B (P2): addition of S. cerevisiae by $0.5 \%$, and treatment C (P3 ): S. cerevisiae dose of $0.8 \%$. Application of S. cerevisiae uses a coating method with a frequency of 2 times a day. The parameters observed included fish health status (total red blood cells and white blood cells, hematocrit, hemoglobin, and blood glucose) as well as production parameters such as absolute growth, daily growth rate, total feed consumption, feed conversion ratio, survival rate. The results showed that the absolute growth rate and the highest daily growth rate were found in treatment (P2), respectively $21.86 \pm 10.05$ grams and $0.86 \pm$ $0.38 \%$. On the other hand, the lowest FCR value was found in treatment (P3), namely $1: 1.25 \pm 0.60$. This shows that the provision of S. cerevisiae has a positive impact on increasing red blood cells, white blood cells, and the growth performance of the fish.

Keywords: Erythrocytes, Leukocytes, Growth, Hemibagrus nemurus

\section{PENDAHULUAN}

Ikan Baung (Hemibagrus nemurus)

merupakan salah satu spesies ikan air tawar spesies asli perairan umum

Indonesia, khususnya di daerah Sumatera dan Kalimantan (Sari et al., 2009). Ikan baung memiliki daging yang tebal, lembut, cita rasa yang enak dan guring sehingga sering dijadikan sebagai bahan utama pembuatan kerupuk basah, ikan pindang maupun ikan asap. Ikan baung juga memiliki nilai ekonomis tinggi, di Kalimantan Barat harga jual ikan baung mencapai Rp. 60.000,00 -. 70.000,/kg. Kegiatan budidaya ikan baung telah lama dikenal di Indonesia namun produktifitasnya tidak sebesar ikan lain yang lebih populer. Kegiatan budidaya ikan baung dapat dilakukan secara ekstensif maupun intensif. Namun menurut beberapa pengamatan menunjukan bahwa masih sangat minim penerapan budidaya ikan baung secara intensif dan lebih banyak penggunaan teknologi ekstensif pada budidaya ikan baung dengan cara penggunaan pakan yang relatif tidak terukur. Penggunaan pakan buatan yang berlebih akan membebani carring capacity media budidaya, penumpukan sisa pakan dan limbah sisa metabolisme ikan (Supono, 2015). Hal tersebut akan berdampak pada produktifitas budidaya ikan baung secara berkelanjutan.

Penumpukan sisa pakan dan limbah sisa metabolisme ikan jika tidak dikelola dengan baik akan bersifat racun dan bisa berdampak buruk bagi pertumbuhan dan kesehatan ikan. Salah satu alternatif yang sering digunakan oleh pembudidaya ikan untuk mengatasi permasalahan diatas adalah dengan pemberian antibiotik, namun penggunaan antibiotik di dalam kegiatan budidaya perikanan telah lama dibatasi karena dapat meninggalkan residu pada daging ikan dan dapat berdampak buruk bagi manusia yang 
mengonsumsinya. Pengendalian residu antibiotik telah diatur dalam peraturan menteri kelautan dan perikanan Republik Indonesia nomor 39 tahun 2015 (PERMEN-KP, 2015). Salah satu bahan alami yang aman dan murah dalam kegiatan budidaya menjadi salah satu alternatif dalam mengendalikan penyakit dan meningkatkan laju pertumbuhan ikan adalah penggunaan yeast.

Yeast (khamir) merupakan salah satu mikroorganisme dari jenis fungi yang bersifat eukariot dan berbentuk uniseluler (Widiastutitik. dan Nur, 2014). Salah satu jenis yeast atau khamir yang sering digunakan dalam kegiatan budidaya ikan adalah Saccharomyces cerevisiae (Ahmad. R.Z, 2008). Penggunaan S. cerevisiae dalam kegiatan budidaya perikanan memiliki beberapa keuntungan yakni mampu meningkatkan respon inflamasi dari sistem imun nonspesifik ikan (Reque et al., 2010).

Manurung dan Nose (2018) juga menambahkan bahwa pemberian ragi roti dapat meningkatkan pertumbuhan ikan bawal. Hasil penelitian Razak et al., 2017 juga mampu meningkatkan laju pertumbuhan mutlak dan pertumbuhan spesifik ikan mas. Pemberian probiotik dan sinbiotik (S. cerevisiae dan MOS) mampu meningkatkan pertumbuhan, respons imun, dan kelangsungan hidup ikan mas yang diuji tantang dengan bakteri A. hidrophyla (Widyastuti, 2016).

Keunggulan dari ikan baung diantaranya dapat dijadikan sebagai sumber protein baik bagi masyarakat dalam bentuk segar maupun dalam bentuk olahan. Ikan baung telah lama dijadikan komoditas budidaya oleh masyarakat. Kegiatan budidaya ikan baung dapat dilakukan secara alami maupun secara intensif. Budidaya sistem intensif lebih menjanjikan karna mampu meningkatkan hasil produksi dan sistem ini telah menggunakan pakan buatan sebagai sumber energi ikan.

Akan tetapi, salah satu permasalahan dalam budidaya intensif adalah air buangan budidaya yang berdampak pada penurunan kualitas perairan di lingkungan sekitar lokasi budidaya, karena akumulasi bahan organik dari sisa pakan maupun feses (Fanani, 2018). Selain itu, penggunaan pakan yang berlebihan juga akan meningkatkan limbah sisa metabolisme ikan berupa feses dan urin. Jika hal ini dibiarkan terus menerus maka limbah sisa 
pakan dan limbah sisa metabolisme akan merusak kualitas air seperti meningkatkan kadar amoniak dalam air yang bersifat toksik bagi ikan. Salah satu alternatif untuk mengatasi terjadinya penumpukan limbah beracun pada media budidaya dengan penggunaan S. cerevisiaei yang mampu meningkatkan nafsu makan ikan, membantu usus mengurai pakan lebih cepat dan efisien (Rajagukguk B.B, dkk, 2017).

Probiotik dengan kandungan $S$. cerevisiaei merupakan salah satu mikroorganisme yang sering dipakai dalam kegiatan budidaya perikanan yang dianggap mampu meningkatkan laju pertumbuhan dan mampu meningkatkan kelulushidupan ikan (Diana, dkk, 2017). Tujuan dari penelitian ini adalah untuk mengetahui pengaruh penggunaan dosis yang tepat dalam penggunaan ragi $S$. cerevisiae pada pakan ikan terhadap jumlah sel darah merah dan darah putih, serta terhadap pertumbuhan ikan baung.

\section{METODE PENELITIAN}

\section{Rancangan penelitian}

Penelitian ini rencananya dilaksanakan di workshop program studi Teknologi Budidaya Perikanan mulai dari tanggal 8 Juli - 30 November 2019. Penelitian ini menggunakan bak fiber yang disekat dengan waring menjadi 4 bagian $\left(100 \times 50 \times 7 \mathrm{~cm}^{3}\right)$. Ukuran ikan baung yang digunakan adalah $5-7 \mathrm{~cm}$, dengan kepadatan 10 ekor/sekat dan dipelihara selama 60 hari.

Penelitian ini menggunakan rancangan acak lengkap (RAL) dengan 4 perlakuan dan 3 ulangan. Perlakuan yang digunakan adalah penambahan ragi $(S$. cerevisiae) pada pakan buatan (pelet) dengan dengan dosis berbeda sebagai berikut:

a. Perlakuan (K): Kontrol tanpa penambahan $S$. cerevisiae pada pakan ikan

b. Perlakuan (P1): Penambahan 0,2\% S. cerevisiae pada pakan ikan

c. Perlakuan (P2): Penambahan 0,5\% S. cerevisiae pada pakan ikan

d. Perlakuan (P3): Penambahan 0,8\% S. cerevisiae pada pakan ikan

\section{Pengambilan Sampel}

Parameter yang diamatai dalam penelitian ini adalah total sel darah merah dan darah putih. Dimana sampel darah diambil menggunakan pipet pulir sampai skala $0,5 \mathrm{ml}$, kemudian ditabahkan 
larutan pewarna (hayem) sampai skala 101 dan dihomogenkan. Disisi lain, pengambilan sel darah putih dilakukan dengan menggunakan pipet bulir putih sampai skala 0,5 ml, kemudian ditambahkan larutan Turk sampai skala 11 dan dihomogenkan. Selanjutnya, sampel darah yang telah tercampur diletakkan di atas haemocytometer kemudian diamati di bawah mikroskop, dan dihitung berdasarkan perhitungan menurut (Blaxhall dan Daisley, 1973).

\section{Parameter pengamatan}

Parameter pengamatan dalam peneliitian ini terdiri dari parameter kesehatan (total sel darah merah dan darah putih), serta parameter pertumbuhan seperti (laju pertumbuhan spesifik, FCR, dan kelangsungan hidup) menurut perhitungan berikut:

Total sel darah:

$\sum$ sel darah $=$

$\sum$ sel hitung $x$ Faktor pengencer

Selanjutnya, perhitungan Laju pertumbuhan mutlak dan spesifik, rasio konversi pakan dan kelulushidupan dihitung menurut (Zonneveld, et al., 1991) sebagai berikut:

\section{Laju pertumbuhan mutlak:}

$$
\mathbf{W}=\mathbf{W t}-\mathbf{W o}
$$

Laju pertumbuhan:

$$
L P H=\frac{\ln W t-\ln W o}{t} x 100 \%
$$

Rasio Konversi Pakan:

RKP

$$
=\frac{\sum \text { pakan }}{(W t+W m)-W o} x 100 \%
$$

Tingkat kelangsungan hidup:

$$
T K H=\frac{N t}{N o} x 100 \%
$$

Keterangan:

$\sum$ Pakan: Jumlah pakan yang diberikan selama pemeliharaan $(\mathrm{g})$

Wt :Biomassa diakhir pemeliharaan (g)

Wm: Biomassa yang mati selama pemeliharaan $(\mathrm{g})$

Wo : Biomassa pada awal pemeliharaan $(\mathrm{g})$

$\mathrm{Nt}$ : Jumlah yang hidup di akhir pemeliharaan (ekor)

Wt : Jumlah yang hidup di awal pemeliharaan (ekor)

\section{Analisis data}

Data status kesehatan dan kinerja pertumbuhan ikan yang diperoleh selama penelitian akan dianalisis secara kuantitatif menggunakan analisis varian satu arah (one way ANOVA) melalui program SPSS dengan selang kepercayaan 95\%, dan dilanjutkan dengan uji Tuckey. 


\section{HASIL DAN PEMBAHASAN}

Hasil pengamatan gambaran darah ikan baung yang dipelihara dengan menggunakan pakan yang dicampur dengan $S$. cerevisiae dapat dilihat pada (Tabel 1). Hasil pengamatan pertumbuhan ikan baung dengan menggunakan penambahan $S$. cerevisiae pada pakan buatan menunjukan nilai yang berbeda dari masing masing perlakuan (Tabel 2). Penambahan S. cerevisiae telah memberikan dampak yang baik buat status kesehatan dan pertumbuhan ikan baung, dimana diketahui bahwa nilai sel darah merah ikan pada hari ke -10 menunjukkan bahwa dosis $S$. cerevisisae sebesar $0,2 \%, \quad 0,5 \%$ dan $0,8 \%$ memberikan pengaruh nyata dibandingkan perlakuan kontrol (Tabel 1). Selanjutnya, perlakuan terbaik dari semua perlakuan terdapat pada penambahan $S$. cerevisiae senbanyak $0,8 \%(\mathrm{P} 3)$.

Tabel 1.Total sel darah merah (SDM) dan total sel darah putih (SDP) pada ikan baung yang diperi pakan dengan penambahan ragi komersil (S. cerevisiae)

\begin{tabular}{cccccc}
\hline Parameter Uji & Hari Ke- & P0 & P1 & P2 & P3 \\
\hline SDM $\left(\times 10^{6} \mathrm{sel} / \mathrm{mm}^{3}\right)$ & 0 & $1.50 \pm 0,23^{\mathrm{a}}$ & $1.50 \pm 0,23^{\mathrm{a}}$ & $1.50 \pm 0,23^{\mathrm{a}}$ & $1.50 \pm 0,23^{\mathrm{a}}$ \\
& 10 & $1.01 \pm 0,04^{\mathrm{c}}$ & $1.30 \pm 0,03^{\mathrm{b}}$ & $1.33 \pm 0,02^{\mathrm{b}}$ & $1.42 \pm 0,04^{\mathrm{a}}$ \\
& 20 & $2.66 \pm 0,03^{\mathrm{a}}$ & $1.74 \pm 0,04^{\mathrm{b}}$ & $1.27 \pm 0,04^{\mathrm{b}}$ & $1.27 \pm 0,03^{\mathrm{b}}$ \\
$\mathrm{SDP}$ & 30 & $2.72 \pm 0,17^{\mathrm{a}}$ & $1.54 \pm 0,39^{\mathrm{b}}$ & $1.19 \pm 0,20^{\mathrm{b}}$ & $1.67 \pm 0,61^{\mathrm{b}}$ \\
$\left(\mathrm{x} 10^{4} \mathrm{sel} / \mathrm{mm}^{3}\right)$ & 0 & $2.21 \pm 0,21^{\mathrm{a}}$ & $2.21 \pm 0,21^{\mathrm{a}}$ & $2.21 \pm 0,21^{\mathrm{a}}$ & $2.21 \pm 0,21^{\mathrm{a}}$ \\
& 10 & $2.44 \pm 0,12^{\mathrm{a}}$ & $2.53 \pm 0,21^{\mathrm{a}}$ & $2.79 \pm 0,09^{\mathrm{a}}$ & $2.68 \pm 0,19^{\mathrm{a}}$ \\
& 20 & $2.60 \pm 0,08^{\mathrm{a}}$ & $2.82 \pm 0,09^{\mathrm{a}}$ & $2.80 \pm 0,11^{\mathrm{a}}$ & $2.82 \pm 0,09^{\mathrm{a}}$ \\
& 30 & $2.42 \pm 0,30^{\mathrm{a}}$ & $2.94 \pm 0,03^{\mathrm{b}}$ & $3.16 \pm 0,04^{\mathrm{b}}$ & $2.84 \pm 0,04^{\mathrm{b}}$ \\
\hline
\end{tabular}

Ket: Huruf superscript yang berbeda ditiap baris pada hari yang sama menunjukkan perbedaan secara statistik (Uji Tuckey; p <0,05). P0 = perlakuan kotrol tanpa penambahan ragi komersil; P1, P2, P3 masing masing dengan penambahan ragi komersil $0,2 \%, 5 \%$ dan $8 \%$.

Nilai sel darah merah perlakuan kontrol mengalami peningkatan tertinggi pada perlakuan kontrol (tanpa penambahan $S$. cerevisiae pada pakan) jika dibandingkan dengan perlakuan P1 $(0,2 \%)$, P2 $(0,5 \%)$ dan P3 (0,8\%) selama pengamatan pada hari ke 20 - 30. Dimana terjadi peningkatan masing - masing sebesar $2.66 \pm 0,03 \times 10^{6}$ dan $2.72 \pm 0,17$ $\mathrm{x} 10^{6}$. Kami menduga, tingginya peningkatan sel darah tersebut disebabkan ikan dalam kondisi stres. Hal ini didukung oleh Wedemeyer dan Yasutake (1977) yang menyatakan bahwa tingginya nilai total sel darah merah ikan 
mengindikasikan ikan lagi berada dalam kondisi stres. Meskipun demikian peningkatan sel darah merah pada setiap perlakuan masih dalam kisaran yang baik. Jumlah sel darah merah ikan teleostei berkisar antara $1,05-3,0 \times 10^{6} \mathrm{sel} / \mathrm{mm}^{3}$ (Irianto, 2005). Selain itu, jumlah eritrosit pada masing-masing spesies ikan berbeda, tergantung dari aktivitas ikan (Fujaya, 2004).

Tabel 2. Jumlah konsumsi pakan (JKP), mutlak, laju pertumbuhan harian (LPH), feed convertion rasio (FCR), dan tingkat kelangsungan hidup (SR) pada ikan baung yang diperi pakan dengan penambahan ragi komersil (S. cerevisiae)

\begin{tabular}{lcccc}
\hline Perlakuan & P0 & P1 & P2 & P3 \\
\hline JKP & $171.67 \pm 10,41^{\mathrm{a}}$ & $155.00 \pm 8,66^{\mathrm{a}}$ & $130.00 \pm 45,00^{\mathrm{a}}$ & $155.00 \pm 10,00^{\mathrm{a}}$ \\
Mutlak & $17.70 \pm 3,09^{\mathrm{a}}$ & $17.81 \pm 5,01^{\mathrm{a}}$ & $21.86 \pm 10,05^{\mathrm{a}}$ & $20.96 \pm 7,89^{\mathrm{a}}$ \\
LPH & $0.78 \pm 0,13^{\mathrm{a}}$ & $0.75 \pm 0,22^{\mathrm{a}}$ & $0.86 \pm 0,38^{\mathrm{a}}$ & $0.84 \pm 0,31^{\mathrm{a}}$ \\
FCR & $1.56 \pm 0,20^{\mathrm{a}}$ & $1.34 \pm 0,51^{\mathrm{a}}$ & $1.25 \pm 0,69^{\mathrm{a}}$ & $1.25 \pm 0,60^{\mathrm{a}}$ \\
SR & $63.33 \pm 11,55^{\mathrm{a}}$ & $70.00 \pm 0,00^{\mathrm{a}}$ & $60.00 \pm 10,00^{\mathrm{a}}$ & $70.00 \pm 10,00^{\mathrm{a}}$ \\
\hline
\end{tabular}

Ket: Huruf superscript yang berbeda ditiap baris pada hari yang sama menunjukkan perbedaan secara statistik (Uji Tuckey; $\mathrm{p}<0,05) . \mathrm{P} 0$ = perlakuan kotrol tanpa penambahan ragi komersil; P1, P2, P3 masing masing dengan penambahan ragi komersil $0,2 \%, 5 \%$ dan $8 \%$.

Nilai sel darah putih yang diperoleh dari hasil pengamatan menunjukkan peningkatan dari awal pemeliharaan hingga hari terakhir pemeliharaan. Pada hari ke 30 pemeliharaan terjadi peningkatan sel darah putih yang berbeda nyata antara perlakuan kontrol dan perlakuan dengan penambahan $S$. cerevisiae pada pakan. Peningkatan nilai sel darah putih diduga disebabkan adanya peran dari $S$. cerevisiae yang diduga mampu merangasang respon imun pada ikan. Sel darah putih ikan berkisar antara 20.000-150.000 sel $/ \mathrm{mm}^{3}$ (Moyle dan
Chech, 1988). Nilai sel darah putih berfungsi sebagai sistem pertahanan dalam tubuh untuk melawan patogen di daerah yang terinfeksi dan sedang mengalami perdangan. Peningkatan nilai sel darah putih mengindikasikan bahwa terjadi peningkatan respon imun didalam tubuh. Hal ini juga didukung oleh Rahma dkk (2001), yang menyatakan bahwa peningkatan sel leukosit atau sel darah putih merupakan refleksi keberhasilan sistem imunitas ikan dalam mengembangkan respon imunitas seluler 
(non spesifik) sebagai pemicu untuk respon kekebalan.

Berdasarkan hasil pengamatan pertumbuhan mutlak, laju pertumbuhan harian, FCR dan SR diketahui mengalami pertumbuhan namun tidak memberikan pengaruh yang berbeda nyata antar perlakuan. Laju perumbuhan mutlak dan laju pertumbuhan harian tertinggi terdapat pada perlakuan (P2) masing - masing sebesar $21.86 \pm 10,05$ gram dan 0.86 $\pm 0,38 \%$. Nilai FCR terendah terdapat pada perlakuan (P3) yaitu sebesar $1,25 \pm 0,60$.

Pemberian ragi roti dapat meningkatkan pertumbuhan ikan bawal (Manurung dan Nose, 2018). Selain itu, mampu meningkatkan laju pertumbuhan mutlak dan pertumbuhan spesifik ikan mas Hasil (Razak et al., 2017). Lebih lanjut, widyastuti (2016), mengatakan bahwa pemberian probiotik S. cerevisiae dan sinbiotik (S. cerevisiae dan MOS) dalam pakan mampu meningkatkan kinerja pertumbuhan, respons imun, dan kelangsungan hidup ikan mas yang diuji tantang dengan bakteri A. hidrophyla.

\section{KESIMPULAN}

Kesimpulan dari hasil penelitian menunjukkan bahwa pemberian ragi komersil (S. cerevisiae) mampu memberikan dampak yang positif terhadap peningkatan sel darah merah, sel darah putih serta performa pertumbuhan ikan baung.

\section{UCAPAN TERIMA KASIH}

Terima kasih sebesar besarnya kami tujukan kepada Unit Penelitian dan Pengabdian Pada Masyarkaat (UPPM) Polnep atas bantuan teknis dan non teknis terhadap pelaksanaan penelitian, terima kasih juga kami ucapkan kepada Manajemen Prodi dan tim Workshop Budidaya Perikanan Prodi Teknologi Budidaya Perikanan PDD Kapuas Hulu dan segenap civitas akademia yang berkontribusi dalam terselsaikanya peneletian ini.

\section{DAFTAR PUSTAKA}

Ahmad, R. Z, 2008. Pemanfaatan cendawan untuk meningkatkan produktivitas dan kesehatan ternak. Jurnal Litbang Pertanian, 27(3):19. 
Diana C., Fronthea Swastawati, Ima Wijayanti, Ambaryanto, Bambang Cahyono. 2018. Penggunaan Probiotik Guna Meningkatkan Pertumbuhan, Efisiensi Pakan, Tingkat kelulushidupan dan Nilai Nutrisi Ikan Bandeng (Chanos chanos). Indonesian Journal of Fisheries Science and Technology, 13(2): 119-125.

Fanani, A. N., Rahardja, B. S., \& Prayogo, P, 2018. Efek Padat Tebar Ikan Lele Dumbo (Clarias Sp.) yang Berbeda terhadap Kandungan Amonia $\left(\mathrm{NH}_{3}\right)$ dan Nitrit $\left(\mathrm{NO}_{2}\right)$ dengan Sistem Bioflok. Journal of Aquaculture Science, 3(2), 85-93.

Fujaya, Y. 2004. Fisiologi ikan. Penerbit Rineka Cipta.

Irianto, A. 2005. Patologi Ikan Teleostei. Gadjah Mada University Press. Yogyakarta.

Peraturan Menteri Kelautan dan Perikanan Republik Indonesia (Permen KKP RI). 2015. Pengendalian Residu obat Ikan, Bahan Kimia, dan Kontaminan pada Kegiatan Pembudidayaan Ikan Konsumsi. Jakarta.
Rahma, F. W., Mahasri, G., \& Surmartiwi, L. 2015. Pengaruh Pemberian Ekstrak Sargassum sp. dengan Pelarut Metanol pada Pakan terhadap Jumlah Eritrosit dan Differensial Leukosit Ikan Lele Dumbo (Clarias gariepinus). Jurnal Ilmiah Perikanan dan Kelautan, 7(2): 213-218.

Rajagukguk, B. B., Lumenta, C., \& Mokolensang, J. F, 2017. Pemanfaatan ragi (S.cerevisiae) pada formulasi pakan dalam meningkatkan pertumbuhan ikan Nila (Oreochromis niloticus). eJournal budidaya perairan, 5(3).

Razak, AP., Kreckhoff, RL., Watung, JC. 2017. Administarsi Oral Imunostimulan Ragi Roti ( $S$. cerevisiae) untuk Meningkatkan Pertumbuhan Ikan Mas (Cyprinus carpio L). Budidaya Perairan, 5(2): 27-36.

Reque, V. R., de Moraes, J. R. E., de Andrade Belo, M. A., \& de Moraes, F. R. 2010. Inflammation induced by inactivated Aeromonas hydrophila in Nile tilapia fed diets supplemented with Saccharomyces 
cerevisiae. Aquaculture, 300(1-4): $37-42$.

Sari, EP., Mokoginta, I., Jusadi, D. 2009. Pengaruh Pemberian KromiumRagi dalam Pakan Terhadap Kinerja Pertumbuhan Ikan Baung (Hemibagrus nemurus Blkr). Jurnal Ilmu-Ilmu Perikanan Indonesia. 16 (1): 17-23.

Sukenda, W., \& Setiawati, M. (2017). Respons imun dan kinerja pertumbuhan ikan lele, Clarias gariepinus (Burchell 1822) pada budi daya sistem bioflok dengan sumber karbon berbeda serta diinfeksi Aeromonas hydrophila. Jurnal Iktiologi Indonesia, 16(3): 309-323.

Supono, 2015. Manajemen Tata Lingkungan Akuakultur. Plantaxia Yogyakarta.

Widyastuti, HSC. 2016. Pemberian Probiotik Saccharomyces cerevisiae dan Prebiotik Mannan Oligosakarida untuk Pengendalian Infeksi Aeromonas hydrophila pada Ikan Mas Cyprinus carpio. [Tesis]. Sekolah Pascasarjana. Institut Pertanian Bogor. Bogor.
Wedemeyer, G.A and Yasutke. 1977. Clinical Methods for The Assessment on The Effect of Enviromental Stress on Fish Health. Technical Paper of The US Departement of The Interior Fish and the Wildlife Service, 89: 1-17.

Widiastutik. N dan Nur Hidayatul Alami. 2014. Isolasi dan Identifikasi Yeast dari Rhizosfer Rhizophora mucronata Wonorejo. Jurnal sains dan seni pomits, 3(1): 2337-3520.

Zonnelveld, N., Huisman., A,E., Boon, J. 1991. Prinsip-prinsip Budidaya Ikan. PT. Gramedia Pustaka Utama. Jakarta. 